\title{
Relationship between Socio-Economic Characteristics with Adoption Behaviour of Trained and General Farmers in Some Adopted Villages of KVK System
}

\author{
P. Gajanand ${ }^{1 *}$, A.K. Bandopadhyay ${ }^{2}$, L. Raja ${ }^{1}$ and R. Vishwatej ${ }^{1}$ \\ ${ }^{1}$ Department of Dairy Extension Education, National Dairy Research Institute (NDRI), \\ Karnal, Haryana, India \\ ${ }^{2}$ Department of Extension Education, Bidhan Chandra Krishi Viswavidyalaya (BCKV), \\ Nadia-52, West Bengal, India \\ *Corresponding author
}

\section{A B S T R A C T}

Keywords

Adoption, Farm innovations, General farmers, KVK system, Trained farmers.

Article Info

Accepted:

26 May 2017

Available Online:

10 June 2017
Krishi Vigyan Kendras (KVK) is the district level farm science institutes for speedy transfer of technology to the farmer's fields. The study was conducted in Adilabad district of Telangana during the year 2015-16 to know the relationship between socio-economic characteristics with adoption behaviour of trained and general farmers in some adopted village of KVK system of Adilabad, Telangana. The district and block was selected purposively. Simple random sampling technique was followed for the selection of respondents. Forty trained and forty general farmers were selected randomly from the areas of four Gram panchayats and Adilabad municipal corporation areas. The age, occupation of the farmers is negatively correlated with adoption of farm innovations in case of trained farmers. In case of income positive and significant correlation found between income and adoption level in both trained and general farmers.

\section{Introduction}

Krishi Vigyan Kendras (KVK) is the district level farm science institutes for speedy transfer of technology to the farmer's fields.

Krishi Vigyan Kendras aim to reduce the time lag between generation of technology at the research institutions/university \& its transfer to the farmer's fields for increasing productivity and income from the agriculture and allied sectors on a sustained basis. It is, therefore, also called as a frontline transfer of technology or frontline extension system in the country. Adoption is not only dependent on the practical realization of the superiority of an innovation. There are some latent variables inside the human which largely affects his/her adoption behaviour. These variables are age, education, family type, family size, material possession, risk bearing ability, market orientation etc. These variables are often guided by one's socio-economic status. It is not only influences the adoption behaviour but also influences the factors which affect the adoption behaviour. Here 
attempts have been made to observe, if the socio-economic, socio-psychological, and extension-communication variables have any correlation with adoption of scientific farm innovations in case of trained and general farmers in K.V.K. system. It is discussed by Pearson Correlation Co-efficient values and their significance are tested by student-t test with $(\mathrm{N}-2)$ degrees of freedom at $5 \%$ and $1 \%$ level of significance in two tail test.

\section{Materials and Methods}

This study was conducted in the district of Adilabad, Telangana during 2015 to 2016. On the basis of my objectives of the study, this district has been selected purposively. The study was conducted at the Adilabad block of Adilabad district. This block was purposively selected, because this block comes under the lateritic belt of the district and it is not so agriculturally developed like other blocks of the district. The area is easily accessible to the investigator. These lead to purposively selection of this block. This block consists of twenty-three gram panchayats and Adilabad Municipal Corporation area. Four gram panchayats namely Mavala, Pochera, Jamdapur, Rampur and Adilabad municipal corporation area were selected purposively as per recommendation of agricultural development officer of the block. Simple random sampling technique was followed for the selection of respondents. Forty trained and forty general farmers were selected randomly from the areas of four Gram panchayats and Adilabad municipal corporation areas. The statistical methods coefficient of correlation, mean, and standard deviation was used.

\section{Results and Discussion}

Here attempts have been made to observe, if the socio-economic, socio-psychological, and extension-communication variables have any correlation with adoption of scientific farm innovations in case of trained and general farmers in K.V.K. system. It is discussed by Pearson Correlation Co-efficient values and their significance are tested by student-t test with (N-2) degrees of freedom at 5\% and $1 \%$ level of significance in two tail test.

It is clear from table 1 that the age of the farmers is negatively correlated with adoption of farm innovations in case of trained farmers but it is non-significant. This means lower the ages higher the adoption of farm innovations in case of trained farmers. Same result is found in case of trained farmers by the researchers like Nataraju (1989), and Bandhyopadhyay (1996).

But in case of general farmers, relationship is positive but non-significant, that is higher the ages, higher the adoption level. It differs because younger farmers are daring and adventurous in case of trained farmers but general farmers are not so adventurous (Table 2).

In case of education, it is positively and significantly ( $1 \%$ level) correlated to adoption level of farm innovations in case of trained farmers. In case of general farmers, there is positive and non-significant correlation exist. So higher the education level, higher the rate of adoption process.

This study confirms the study of researchers like Singh et al., (1989), Nataraju (1989). The general education level is higher in case of trained farmers as evident from mean value, which differs trained farmers and general farmers.

Occupation is negatively correlated with adoption of farm innovation in general farmers and positively correlated with adoption of farm innovation in case of trained farmers. There is no significant relationship between trained and general farmers in case of occupation. 
Table.1 Values of the correlation co-efficient of trained farmers

\begin{tabular}{|l|l|}
\hline Variables & $\begin{array}{l}\text { Trained Farmer } \\
\text { (r }- \text { value) }\end{array}$ \\
\hline Age $\left(\mathbf{X}_{\mathbf{1}}\right)$ & -0.045 \\
\hline Education $\left(\mathbf{X}_{\mathbf{2}}\right)$ & $0.449^{* *}$ \\
\hline Occupation $\left(\mathbf{X}_{\mathbf{3}}\right)$ & 0.203 \\
\hline Income $\left(\mathbf{X}_{\mathbf{4}}\right)$ & $0.556^{* *}$ \\
\hline Caste $\left(\mathbf{X}_{\mathbf{5}}\right)$ & 0.017 \\
\hline Family Type $\left(\mathbf{X}_{\mathbf{6}}\right)$ & 0.079 \\
\hline Family Size $\left(\mathbf{X}_{\mathbf{7}}\right)$ & 0.100 \\
\hline Holding Size $\left(\mathbf{X}_{\mathbf{8}}\right)$ & $0.954^{* *}$ \\
\hline Material Possession $\left(\mathbf{X}_{\mathbf{9}}\right)$ & $0.472^{* *}$ \\
\hline Social Participation $\left(\mathbf{X}_{\mathbf{1 0}}\right)$ & $0.681^{* *}$ \\
\hline Attitude Study $\left(\mathbf{X}_{\mathbf{1 1}}\right)$ & $0.683^{* *}$ \\
\hline Risk Orientation $\left(\mathbf{X}_{\mathbf{1 2}}\right)$ & $0.428^{* *}$ \\
\hline Market Orientation $\left(\mathbf{X}_{\mathbf{1 3}}\right)$ & $0.644^{* *}$ \\
\hline Production Orientation $\left(\mathbf{X}_{\mathbf{1 4}}\right)$ & $0.441^{* *}$ \\
\hline Extension Communication $\left(\mathbf{X}_{\mathbf{1 5}}\right)$ & -0.074 \\
\hline Extension Contact $\left(\mathbf{X}_{\mathbf{1 6}}\right)$ & $0.443^{* *}$ \\
$*$ Correlation is significant at 5\% level of significance (2-tail test) \\
** Correlation is significant at $1 \%$ level of significance (2-tail test)
\end{tabular}

Table.2 Values of the correlation co-efficient of general farmers

\begin{tabular}{|l|l|}
\hline Variables & $\begin{array}{l}\text { General Farmer } \\
\text { (r }- \text { value })\end{array}$ \\
\hline Age $\left(\mathbf{X}_{\mathbf{1}}\right)$ & 0.154 \\
\hline Education $\left(\mathbf{X}_{\mathbf{2}}\right)$ & 0.140 \\
\hline Occupation $\left(\mathbf{X}_{\mathbf{3}}\right)$ & -0.208 \\
\hline Income $\left(\mathbf{X}_{\mathbf{4}}\right)$ & $0.862^{* *}$ \\
\hline Caste $\left(\mathbf{X}_{\mathbf{5}}\right)$ & $0.915^{* *}$ \\
\hline Family Type $\left(\mathbf{X}_{\mathbf{6}}\right)$ & 0.019 \\
\hline Family Size $\left(\mathbf{X}_{\mathbf{7}}\right)$ & $0.970^{* *}$ \\
\hline Holding Size $\left(\mathbf{X}_{\mathbf{8}}\right)$ & $0.886^{* *}$ \\
\hline Material Possession $\left(\mathbf{X}_{\mathbf{9}}\right)$ & -0.046 \\
\hline Social Participation $\left(\mathbf{X}_{\mathbf{1 0}}\right)$ & 0.167 \\
\hline Attitude Study $\left(\mathbf{X}_{\mathbf{1 1}}\right)$ & -0.109 \\
\hline Risk Orientation $\left(\mathbf{X}_{\mathbf{1 2}}\right)$ & 0.015 \\
\hline Market Orientation $\left(\mathbf{X}_{\mathbf{1 3}}\right)$ & -0.109 \\
\hline Production Orientation $\left(\mathbf{X}_{\mathbf{1 4}}\right)$ & -0.015 \\
\hline Extension Communication $\left(\mathbf{X}_{\mathbf{1 5}}\right)$ & $0.967^{* *}$ \\
\hline Extension Contact $\left(\mathbf{X}_{\mathbf{1 6}}\right)$ & $0.995^{* *}$ \\
\hline \multirow{2}{*}{ * Correlation is significant at 5\% level of significance (2-tail test) } \\
** Correlation is significant at 1\% level of significance (2-tail test)
\end{tabular}


That means higher the agricultural occupation higher the adoption of farm innovations in case of trained farmers but in general farmers higher the agricultural occupation lowers the adoption of farm innovations. It is because the farmer is more attached to agricultural occupation more the adoption and farmers who have less agricultural occupation obviously they have lower the adoption of farm innovations. The same result was found by Obasi et al., (1994). In case of income positive and significant (1\% level) correlation found between income and adoption level in both trained and general farmers. This means higher the income levels higher the adoption levels in both type of farmers. Positive but non-significant correlation is found between caste and adoption level in trained farmers.

In case of general farmers positive and significant correlation found between caste and adoption level. This means higher caste people adopt more scientific farm innovations. In case of size of holding, there is positive and significant ( $1 \%$ level) relationship with adoption level in case of both the trained and general farmers. Trained farmers have more size holding than that of general farmers, as it is clear from mean values. So for trained farmers, higher the size of holding higher the rate of adoption. Similar results were found by Bandhyopadhyay (1986) in case of general farmers. Positive and non-significant correlation found between social participation and adoption level in case of general farmers. That is higher the attitude towards improve farm practices, higher the adoption of farm innovations. Similar result was found by the researchers like Bandhyopadhyay (1986), Singh (1990).

There is positive and significant (1\% level) relationship exists between risk orientation and adoption of farm innovations in case of trained farmers but it is non-significant in case of general farmers. This means higher the risk orientation higher the adoption level. There is positive and significant (1\% level) relationship found between market orientation and adoption of farm innovations in case of trained farmers but it is negative and nonsignificant in case of general farmers.

In case of extension contact, highly positive and significant ( $1 \%$ level) relationship with adoption of farm innovations in both the trained and general farmers. This is because level of risk orientation, market orientation, and extension contact are higher in case of contact farmers as shown in the mean values.

There is positive and significant (1\% level) relationship found between production orientation and adoption of farm innovations in case of trained farmers but in general farmers it is negative and non-significant. In extension communication, positive and significant (1\% level) relationship found in case of general farmers.

From the above study it is concluded as sociopsychological and extension communication variables have greater role in adoption of farm innovations in the area obviously they take determining role for the difference of adoption level between trained and general farmers as it is found in the study. So, it can be concluded that, the trained farmers with their higher adoption level should become the vanguard for the dissemination of agricultural technologies to the other farmers. They themselves can make the bridge to reduce the gap of adoption level between trained and general farmers and that will be undoubtedly helpful for the betterment of agriculture in the area.

\section{References}

Bandyopadhyay, A.K. (1986). A study on adoption of Rabi programme and investment pattern of additional 
income by the farmers of Sunderban, W.B. Unpublished Ph.D. Thesis, Department of Agricultural Extension, Bidhan Chandra Krishi Krishi Viswavidyalaya.

Nataraju, M.S. (1989). A study of adoption behaviour of small and marginal farmers in Karnataka. Livestock Adviser. 14 (11): 13-19.

Obasi, M.O.; Obinne, C.P.; Ejembi, E.P. (1994). Appraisal of selected factors that influence the adoption of improved farm practices among soyabean farmers in Benue state, Nigeria. Journal of Rural Development and Administration. 26 (3): 78-91.

Singh, B. (1990). Socio-personal correlates of adoption behaviour and information needs of tribal farmers in respect to rainfed technology. Indian Journal of Extension Education. 26 (3-4): 53-58.

\section{How to cite this article:}

Gajanand, P., A.K. Bandopadhyay, L. Raja and Vishwatej, R. 2017. Relationship between Socio-Economic Characteristics with Adoption Behaviour of Trained and General Farmers in Some Adopted Villages of KVK System. Int.J.Curr.Microbiol.App.Sci. 6(6): 2215-2219. doi: https://doi.org/10.20546/ijcmas.2017.606.262 